Carlos Guardado da Silva

Universidade de Lisboa, Faculdade de Letras, Centro de Estudos Clássicos

Luís Corujo

Universidade de Lisboa, Faculdade de Letras, Centro de Estudos Clássicos

Jorge Revez

Universidade de Lisboa, Faculdade de Letras, Centro de Estudos Clássicos

\title{
The Classification Plan for Local Administration Portuguese Archives and the Knowledge Organization in practice
}

\begin{abstract}
This paper presents recent developments in Portuguese local archives' classification policies. Following several professional workgroups and reinforced with a political mandate, local administration archives are putting in practice a new knowledge organization approach through the development of a national Classification Plan for Local Administration (CPLA). New archival legislation is ready to be officialy published and its impact is expected to largely modify administration practices. The main objective of the study is to discuss the knowledge organization solutions embedded in the creation of CPLA. To achieve this goal, a literature review was performed, together with a project management approach, exploring a qualitative analysis of the problems and the solutions found during CPLA's design. The Functional Macrostructure for Public Administration information is the main framework for the development of CPLA, and contributes to the emergence of a new paradigm in Information Management. Such paradigm intersects functions with business processes, transversally and supra-institutionally, and considers the different public administration bodies as open systems. As an outcome, the public administration and, in particular, the archival community receive a new standardized information management tool that serves the classification, appraisal and selection of archival information.
\end{abstract}

\section{Introduction}

This paper presents recent developments in Portuguese local archives' classification policies. Following several professional workgroups and reinforced with a political mandate, local administration archives are putting in practice a new knowledge organization approach through the development of a national Classification Plan for Local Administration (CPLA). New archival legislation is ready to be officialy published and its impact is expected to largely modify administration practices.

The main objective of the study is to discuss the knowledge organization (Hjørland 2016) solutions embedded in the creation of CPLA. To achieve this goal, a literature review was performed, together with a project management methodology (Abadal 2004), exploring a qualitative approach of the problems and the solutions found during CPLA's design.

The CPLA initiative has been regularly mentioned in Portuguese literature. There are papers written by authors from the archival policy coordinating body (Lourenço et al. 2019), written by members of the working groups or who have already performed locally early adoption of the new methodologyy (Neves 2014; Melo 2016; Negrão 2017; Torres 2018) and presented by scholars (Silva 2013, 2016, 2019). 
The previous legislation regarding public information management had the advantages of streamlining procedures and costs through the elimination of worthless records that had fulfilled their administrative function. However, the old legislation tended to be applied downstream of its production, repeatedly causing an entropy in the public administration services. In the new scenario, the adoption of more objective criteria and a relational methodology established between business processes strongly recommend that appraisal should occur in a genetic phase, thus enhancing the continuous management of information flows that result from the internal and external procedures, from the moment of their production until their permanent conservation or permanent disposal (Silva 2016).

\section{Functional Macrostructure}

In an attempt to create a set of tools of information classification for its entire public administration, a Portuguese collective initiative conceived a new structure with several theoretical and practical implications, called Functional Macrostructure. The process was led by DGLAB (Directorate-General of Book, Archives and Libraries), the coordinating body for the national archival policy, and involved more than two hundred public administration organizations (central, regional and local) since 2004 (Silva 2016).

The Functional Macrostructure is a conceptual representation of functions performed by public sector organizations, which develops on two levels: (a) Top-level instances representing public administration functions; (b) Second-level instances representing the subfunctions into which the first can be decomposed.

It has a global and integrative perspective of the public sector, which overlaps the analysis of the functions of each single organization, taking as greater value the semantic interoperability in the informational exchanges of the administration bodies. The Functional Macrostructure aims to increase semantic interoperability in information exchange between public administration services, responding to the need for a common language for information representation, and ensuring the ability of a system (digital or not) to communicate transparently with another system. It also aims to provide a classification model (in syntax and semantics) that can be understood by different entities of the public administration. Finally, another goal is to promote the use of a single structure to classify and organize public sector records (and archival information that does not materialize in documents, and which it is also necessary to manage), enhancing greater management effectiveness and easier access to information by bodies and citizens, and contribute to transparency in management and to the enhancement of accountability processes.

Since 2012, the Functional Macrostructure achieved a new development stage, surpassing the central Public Administration scope. The goal was to reach local administration governing bodies. This evolution was mainly due to the initiative of a set of municipalities that organized themselves into a cooperative project to carry out a feasibility analysis of the application of the Functional Macrostructure to the functional framework of municipal services and, in the face of a predominantly positive response, to develop a classification plan for local administration.

This new stage underlined the original purpose of the Functional Macrostructure, designed primarily to support functional classification plans. In 2017, DGLAB published the first version of the Consolidated List for classification and appraisal of public sector 
information. This list included already a set of third-level instances representing the business processes and it was the result of several parallel projects concerning the Functional Macrostructure development process. The document presented a hierarchical structure of classes that represent the functions, sub-functions and business processes performed by the Public Administration, from a supra-institutional, cross-functional and functional perspective, including their description and appraisal (administrative retention periods and the final destination of information). It was proposed as a reference for the development of organizational or multi-organizational tools for the classification and appraisal of public information (classification plans and retention schedules).

Since 2018, the Consolidated List was published as open data through the CLAV (Classification and Appraisal of Public Information) Platform. This new tool is ontology-based, including the business processes of entities that perform public functions (Consolidated List), associated with a catalog of the legislation that regulates them and the bodies that execute them, that are responsible for the preservation of the information produced in this context and for the lifecycle management, and retention schedules, derived from the Consolidated List, identifying the classes and information lifecycle associated with business processes (administrative retention deadlines and final destination) for implementation in organizational or multi-organizational context (Lourenço et al. 2019).

\section{Classification Plan for Local Administration}

Referring to the functional dimension, the classification consists of identifying and grouping records and information into classes or categories according to the functional structure and their sub-functions or activities of the various public administration producers, regardless of their nature. However, the adoption of the functional classification is complex because it is based on the clear distinction between bodies, divisions or services and functions, when administrative units are established, or should be established, based on functional specialization. However, function-based classification is clearly the most stable criterion, being as objective as the organic one if functions are clearly determined (Silva 2019).

The new CPLA, made up of a functional matrix, with the version 0.2 already published in 2014 (Direção-Geral do Livro, dos Arquivos e das Bibliotecas (DGLAB) 2014), is together with the Functional Macrostructure (version 2.0) a decisive management tool for the emergence of a new paradigm in local government archival information management, as it is connected with the universe of all public administration. It was considered advantageous to implement more extensive solutions for the organization of the Administration's information and its interoperability. Instead of each entity creating its own classification plan, the use of an instrument by all entities, safeguarding the specificities of each one, not only guarantees an economy of scale, making public investment more profitable, but also facilitates easier access to information by organizations and citizens (Lourenço and Penteado 2015).

In response to the continuous challenges of administrative modernization and e-government, new policies and instruments for the management of records are required, a requirement that also extends to classification plans. These, for a long time, seem to not respond effectively to the new challenges, if they continue to be considered only as a tool for organizing and describing documentary fonds. Even today, many municipalities 
do not use any classification plan in the management of daily records. On the contrary, the classification plan should be a key instrument in the management of records, as well as reflecting the functions and activities in each organization. If its importance was recognized in traditional information systems, when they existed, in digital information systems, classification is a mandatory and indispensable requirement (Silva 2019).

The CPLA was developed according to the Functional Macrostructure. The first premise for the elaboration of a classification scheme adapted to the reality of the municipal archives was the recognition that there are transversal processes to several public administration bodies. In this sense, the CPLA Working Group, formed in September 2011, by the municipalities of Cascais, Lisbon, Lourinhã, Oeiras, Santarém, Sintra and Torres Vedras, as well as the Municipalized Services of Oeiras-Amadora, with the technical support of DGLAB, and a year later, by the municipalities of Amadora, Alenquer and Beja, concluded that the functions of the central administration are essentially identical to those of the local administration.

Following this starting point, the Working Group proceeded to the identification of specific (from Local Administration), common (to Central Administration) and transversal (between different Local Administration bodies and between Local Administration and Central Administration) business processes. At the end of the first phase (Sept. 2011-Sept. 2012), the identification of business processes, version 0.1 of the Classification Plan was published, putting the document up for discussion to collect contributions from the various bodies of local administration.

In the second phase (Sept. 2012-Feb.2013), the group was expanded with more 45 municipalities as observing members, with online access to the files created so that, in an articulated way, they could send their contributions. Then, a third phase (Feb. - May. 2013) started, through the creation of groups by function, bringing together professionals from local administration and central administration, aiming at the consolidation of common and transversal business processes, in order to standardize their identification and to facilitate interoperability. The fourth phase was the consolidation of the Classification Plan for the public release of version 0.2. The fifth phase will follow, which aims at associating the conservation periods and the final destination with the business processes, and which will introduce the fourth level in the classification code, for the purposes of information appraisal and selection (Silva 2019).

During this course, the project's initial assumptions were maintained, namely: (a) Creation of a single tool with concerns in terms of classification and appraisal; (b) Construction of an instrument that promotes semantic transversality and interoperability; (c) Application of the classification plan to the records (and information) at the stage of its creation or reception. It should be stressed that this plan is not an instrument of retroactive application, nor does it intend to reorganize the documentation already produced; (d) Use of the instrument for the classification of records on paper or other media. It applies to electronic records management systems, as well as electronic information systems in support or business areas; (e) The implementation of the classification plan necessarily implies the adoption of new practices, which may lead to a rearrangement of records organization (Direção-Geral do Livro, dos Arquivos e das Bibliotecas (DGLAB) 2014). 


\section{Knowledge Organization (KO) solutions}

Classification is a term concerning «the assignment of elements to pre-established classes. The wide meaning of classification is the process of distinguishing and distribution kinds of "things" into different groups» (Hjørland 2017). Grounded in theory, CPLA follows a process approach, traditionally more claimed than practiced, but considering the business process concept. This has required the standardization of terminology, since it is a recent concept in the context of information management, as its meaning is not univocal, nor is it entirely acknowledged by archivists (Sabourin 2001; Díaz Rodríguez, Caro Castro, and Hernández Oliveira 2010).

A hierarchical semantic classification structure of the CPLA was developed at three levels, the first two representing the functions and sub-functions of public administration (Functional Macrostructure) and the third level representing the Business Processes. Following KO theory, classification is the intellectual operation for the identification and hierarchical structuring of documents and information of an open archival system that reflects the functions and activities of the agencies involved in the different business processes, based on the principles of interoperability, completeness, transversality and suprainstitutional (exosystemic) approach (Foscarini 2009; Barros 2012; Simões and Freitas 2013).

The fonds extends to the transversality of organizations' processes in suprainstitutional terms. Neither the principle of provenance seems to fit here, since it refers to the uniqueness of the fonds, given to a single producer. As a new paradigm in the archival information management of the public administration is initiated, which considers, in the transversal processes, two or more producers, the concept of background was closely related to the competences of one producer, despite the contradictions between these two concepts.

The CPLA, being a plan grounded in Functional Macrostrucutre, integrates the classes of 1 st and 2nd level (representation of the functions and sub-functions of the public administration) and develops the $3 \mathrm{rd}$ level also in a functional perspective. The $3 \mathrm{rd} \mathrm{lev-}$ els represent, as much as possible, the business processes developed by local administration. Eventually, due to needs derived from the appraisal, 4th levels may be created.

The identification of business processes implied the adoption of the following principles: (i) Interoperability (existence of communication between systems); (ii) Transversality (existence of reciprocal relationships); (iii) Granularity (subdividing a system into smaller parts); (iv) Completeness (complete presentation); (v) Exogeneity (existence of supra-institutional or exosystemic value chains); (vi) Respect for the function (hierarchical dependence on the business process of the 1st and 2nd level classes) (Silva 2019).

In order to obtain a single classification plan for the entire Portuguese public administration, regardless of different materializations, it was necessary to represent the logical path followed in each function for obtaining business processes. Thus, the option was the construction of "concept maps", which would allow to guide, explain and justify the path. This information does not belong to any of the classes, as it is not directly visible in the Classification Plan.

For the subdivision, in order to structure the classification system, the principles or types of semantic relationships between the concepts, proposed by Dahlberg (1978), were followed, namely: 
- Hierarchical relationship or gender and species relationship (when two or more concepts in the subdivision have identical characteristics, and one of them has one more characteristic than the other, that one is more specific, the other is broader);

- Partitive relationship (when between the whole and the parts or between a product and the elements that constitute it);

- Opposition relationship (when contradiction or contrariety);

- Functional relationship (when a function derives from a process, based on the semantic valence of verbs).

First KO solution - Local Administration working group and Coordinating Body leadership and support

Following the initiative of a set of municipalities and their archivists, the first KO solution was the informal working group gathered to work on CPLA (Melo 2016). Altough it seems a managerial option, this initiative exemplifies the social dimension of information systems and networks. Without the involvement of local archives' professional group, it would be quite difficult to connect the work performed in the central hub with the local nodes. The CPLA design was possible based on concerted will, initiative and "appetite" to build a tool that fits the new information management models in those organizations (Melo 2016).

Neves (2014) also highlighted the collaborative work and the harmonization effort between Central and Local Administration entities. This methodology is considered both a condition and a guarantor of the greatest value of the tool: its supra-institutional and supra-organic characteristics. The ability of the different Public Administration entities to interact, sharing information within the scope of the processes in which they intervene, requires the existence of tools for interoperable solutions. However, tools that allow interoperability are not built without articulation between entities that share the same concerns, that intervene in the same processes, that compete together for a service or a final product (Neves 2014).

The aim of the project was never just to build a classification plan for the local administration: from the beginning, it was assumed that the plan would comply with Functional Macrostructure, which implied adopting and assuming its principles and concepts. It therefore means that the objective of the project is based on the promotion of semantic interoperability that serves the objectives of entities that share responsibilities in the provision of public services. The principle of supra-institutional Functional Macrostrucure required to abandon the perspective of Local Administration and to seek the perspective of Public Administration (Neves 2014).

As with any project, a working methodology was determined, which, at first, was exposed by DGLAB. As the work evolved, that is, when the theory was confronted with the practical reality, some concerted revisions were made between DGLAB and the working group. However, strictly speaking, the main guidelines for the survey / classification of Business Processes resulted from the reflections and the work of several years developed when the Functional Macrostrucure was built (Melo 2016).

\section{Second KO solution - Functional-based classification}

Classifying is the intellectual act or operation that consists of grouping elements, which have something (characteristic or property) in common, forming a set or a class. 
The act of classifying allows the creation of classes of elements with connections to each other and distinguish them from other classes that do not contain the same characteristics (Ribeiro 2013). Classification is also the act of identifying and organizing archival information by class and / or category according to the functional structure and respective sub-functions or activities of the various entities that produce public administration information, regardless of its nature (Silva 2013).

The implementation of the CPLA supposes the adoption of a functional approach, by business processes, which may imply changes in administrative practices and, consequently, in the organization of information (Neves 2014). The appraisal process focuses on the attribution of value and on the determination of the producing entity responsible for the retention of the records in the immediate moment, regardless of the reuse of the information (it is appraised in response to what it is; information is valued due to its context of production and not to the potential uses of that information) (Lourenço and Penteado 2015).

The weight of organizational culture, based on management models that have privileged its umbilical or self-centered view, is contrary to the principles on which Functional Macrostrucure is based and which are characterized by the supra-institutional or supraorganic approach. This interorganizational approach allows entities to integrate and share services and information in the pursuit of cross-cutting activities, aiming at the effectiveness and efficiency of Business Processes (Melo 2016).

Only the functional approach allows for the necessary distance from the vices rooted in the tradition of a hierarchical and overly departmentalized administrative model, favorable to the fragmentation of processes, the redundancy of information and duplication of tasks, being therefore adverse to the sharing of information and competitiveness of companies. public organizations. One of the first consequences resulting from the adoption of the functional approach was the redefinition of the methodology used to identify third-level classes. For the purpose of identifying third-level classes in a classification plan built on a functional logic, it is necessary to capture something more stable and common to the different entities, it is necessary to know what they do and not how they do it. It then became evident the need to identify not the documentary processes but the business processes that result from the performance of public functions by the different entities (Neves 2014).

The synergies created in the field of public information management seeks to break with the traditional and obsolete organizational information management, a model that does not comply with the requirements of a tendency to digital administration, capable of responding within acceptable deadlines. Definitely, information management, that is, its classification and appraisal, involves models and tools that are integrated and shared by public agents, at the suprainstitutional level (Melo 2016).

\section{Third KO solution - Business process approach}

The appraisal of information resulting from business processes will imply the adoption of certain principles, among which: (a) Functional provenance (the information produced is no longer linked to a particular producer, being the result of the performance of several producers who work in networks - open systems -, relating more to the functions and activities and less to the organizational structure). Such principle will allow explaining the origin and evolution of organisms, as well as the way they act or interpret 
social reality, focusing on the functional context; (b) Globality (transversal approach to public administration, with the information produced being appraised in its entirety, regardless of the medium); (c) Legality (appraisal of information resulting from the application of the legal regulation); (d) Objectivity and contemporaneity of the judgment (appraisal according to principles, accepted social values, knowledge and technology available at the time of records' creation); (e) Participation (appraisal of information based on the definition of the owner of the business process, as well as on the existence of customer relationships, when existing or other forms of participation); (f) Responsibility (appraisal and selection actions are based on defined and known criteria, with disposal events being demonstrable); (g) Exceptionality (selection of information resulting from exceptional events such as natural disasters); (h) Informational density (nature of information, requiring retention of synthesized information); (i) Partition (when different disposition dates and / or disposal decisions are defined for the information, depending on the stage in the business process); (j) Authenticity / integrity (appraisal of authentic documents); (k) Guarantee (safeguarding the rights of the producing entities and content object) (Silva 2019).

Each member of the working group had to carry out an in-depth study of the underlying principles and values, so that the survey of business processes corresponded to the "spirit" that guided the construction of these tools that promote semantic interoperability. After this analysis, the 19 Functional Macrostrucure functions were then distributed among the participating municipalities (Melo 2016).

The identification of business processes for the constitution of classes is something that stems from the functional approach and requires the adoption of different work methodologies. The Business Process must be identified within the scope of the function to which it belongs (what it is and not for what it serves or how it is), it must be identified taking into account the final product and not the partial or intermediate product, it must not consider the specific procedure for obtaining that product (given that the procedure may vary from entity to entity, or due to legal imperatives) and must take into account the specific legal framework, although it is recognized that there is no univocal relationship between a Business Process and the legislation. The concern in associating the final product with the concept of Business Process led to another principle underlying this project: the principle of transversality that guarantees the identification of the Business Process in its completeness. This is only possible with a supraorganic and supra-institutional approach (Neves 2014).

The work methodology for the survey / classification of business processes is generally characterized in three stages: (1) Investigation work by municipality; (2) Meetings with producer services; (3) Meetings between municipalities and DGLAB. Subsequently, DGLAB proposed the mediation of a supra-institutional harmonization phase of business processes, which took place at a meeting between central and local government entities (Melo 2016).

The construction of the CPLA allowed a structured view of public administration, from the perspective of a single big system, in the articulation of multiple public systems, which tend to be open, shareable and flexible, to the detriment of the traditional positioning in the closed, isolated and inflexible organizational system. Based on the focus on supra-institutional relations established between business processes, which represent a network of highly complex transactions, forming a web in which the public 
administration itself is a recurrent victim, it seeks to clarify the different actions, through the creation of a semantic language that enhances the understanding between services and public bodies in the search for the satisfaction of external and internal customers (Melo 2016).

\section{Conclusion}

This work showed how a common, shared and standardized language was created to represent the functions of public administration, called Functional Macrostructure. In order to deepen the levels of semantic interoperability achieved in this structure, DGLAB developed a Consolidated List for the management of decisions on the classification and appraisal of public information.

A single tool for classifying and appraising archival information is available to all entities of the Portuguese local administration and also other public administration entities. Nowadays, it seems increasingly difficult to understand the classification as a function that deals with the documents of a fonds, this is produced within the scope of an organization's activities, based on the archival principles of provenance and respect for the original order. The standardisation of processes will have to be definitively inserted in the production phase, contributing to an effective management of information and records in the information systems of public administration bodies (Silva 2019).

The paradigm proposed by Portugal is characterized by a new archival approach, a matrix model that crosses functions with business processes. The integration of traditional documentary series into the Functional Macrostrucure is irreconcilable. Such change definitely positions the information manager in the design, planning and development of the information system. Finally, the Functional Macrostructure, as well as the CPLA, contribute to the emergence of a new paradigm in Information Management within the public administration. Such paradigm intersects functions with business processes, transversally and supra-institutionally, and considers the different public administration bodies as open systems. As an outcome, the public administration and, in particular, the archival community receive a new standardized information management tool that serves the classification, but also the appraisal and selection of archival information.

It is expected the publication of the legal diploma that will regulate the classification, appraisal, selection, elimination and conservation of information, in any medium, in the exercise of local administration functions. The administrative procedures associated with them are included, thus streamlining the functions of the archive in guaranteeing rights and duties and in preserving collective memory.

\section{References}

Abadal, Ernest. 2004. Gestión de Proyectos En Información y Documentación. Gijón: Trea.

Barros, Thiago. 2012. ‘A Classificação Funcional Em Arquivística: Uma Análise Da Colaboração Científica Nos Periódicos Archivaria e American Archivist $=$ The Functional Classification in Archival Science: An Analysis of the Scientific Collaboration in the Journals Archivaria and American Archivist'. In 20 Años Del Capitulo Español de ISKO, 157-69. Ferrol: Universidade da Coruña (España). http://hdl.handle.net/2183/11625.

Dahlberg, Ingetraut. 1978. 'Teoria Do Conceito'. Ciência Da Informação 7 (2). http://revista.ibict.br/ciinf/article/view/115. 
Díaz Rodríguez, Alfonso, Carmen Caro Castro, and Luis Hernández Oliveira, eds. 2010. Innovar o Morir : En Torno a La Clasificación = Innovate or Die : Surroundings to the Classificaton. Tabula : Estudios Archivísticos de Castilla y Léon 13. Salamanca: Asociación de Archiveros de Castilla y Léon. https://dialnet.unirioja.es/ejemplar/259171.

Direção-Geral do Livro, dos Arquivos e das Bibliotecas (DGLAB). 2014. Plano de Classificação Da Informação Arquivística Para a Administração Local: Versão 0.2. Lisboa: DGLAB. http://arquivos.dglab.gov.pt/wpcontent/uploads/sites/16/2014/02/PC_AL_2014_01_311.pdf.

Foscarini, Fiorella. 2009. 'Function-Based Records Classification Systems: An Exploratory Study of Records Management Practices in Central Banks'. Phd Thesis, Vancouver: University of British Columbia. http://hdl.handle.net/2429/9310.

Hjørland, Birger. 2016. 'Knowledge Organization'. Knowledge Organization 43 (6): 475-84. http://www.isko.org/cyclo/knowledge_organization.

- 2017. 'Classification'. Knowledge Organization $44 \quad$ (2): 97-128. http://www.isko.org/cyclo/classification.

Lourenço, Alexandra, and Pedro Penteado. 2015. 'A Caminho Da ASIA - Avaliação Suprainstitucional Da Informação Arquivística'. In $12^{\circ}$ Congresso Nacional Da BAD. Évora: BAD. https://www.bad.pt/publicacoes/index.php/congressosbad/article/view/1458/pdf_90.

Lourenço, Alexandra, José Carlos Ramalho, Maria Rita Gago, and Pedro Penteado. 2019. 'Plataforma CLAV: Contributo Para a Disponibilização de Dados Abertos Da Administração Pública Em Portugal'. In EDICIC 2019. Barcelona. http://eprints.rclis.org/38643/.

Melo, Daniel de. 2016. 'Projeto MEF/Autarquias: Construção de Um Plano de Classificação (e de Avaliação) Para a Administração Local'. In Reinventando Os Arquivos No Séc. XXI. Lisboa.

$\mathrm{http}: / /$ arquivomunicipal.cmlisboa.pt/fotos/editor2/Eventos/jornadas\%20iberoamericanas/aml_daniel_de_melo.pdf.

Negrão, Sónia. 2017. 'Análise à Implementação Do Plano de Classificação No Município de Albufeira'. In Da Produção à Preservação Informacional: Desafios e Oportunidades, by Nélson Vaquinhas, Marisa Caxias, and Helena Vinagre. Évora: Cidehus. 10.4000/books.cidehus.2802.

Neves, Helena. 2014. 'Plano de Classificação Da Informação Arquivística Para a Administração Local - Desenvolvimento e Perspetivas de Utilização'. In Arquivística e Competitividade Na Administração Local.

Esposende. https://www.bad.pt/publicacoes/index.php/arquivosmunicipais/article/view/1102/1144.

Ribeiro, Fernanda. 2013. 'O Uso Da Classificação Nos Arquivos Como Instrumento de Organização, Representação e Recuperação Da Informação'. In Informação e/Ou Conhecimento, as Duas Faces de Jano: Atas. Porto: FLUP. http://hdl.handle.net/10216/69659.

Sabourin, Paul. 2001. 'Constructing a Function-Based Records Classification System: Business Activity Structure Classification System'. Archivaria 51: 137-54. https://archivaria.ca/index.php/archivaria/article/view/12797/13999.

Silva, Carlos Guardado da. 2013. 'A Classificação Da Informação Arquivística Da Administração Local Nos Países Ibéricos: Uma Análise Comparada'. In Políticas, Sistemas e Instrumentos. Lisboa: Câmara Municipal de Lisboa, Arquivo Municipal. http://hdl.handle.net/10451/30033. . 2016. 'Knowledge Organization in Portuguese Public Administration: From the Functional Classification Plan to the Creation of an Ontology from the Semantic Web's Perspective'. In Knowledge Organization for a Sustainable World: Challenges and Perspectives for Cultural, Scientific and Technological Sharing in a Connected Society, 290 99. Advances in Knowledge Organization. Rio de Janeiro, Brazil: Ergon Verlag. http://hdl.handle.net/10451/30019. 
2019. 'Para Um Novo Paradigma Na Gestão Da Informação Arquivística Da Administração Local: O Plano de Classificação'. In Investigação Em Ciência Da Informação, 87-107. Ciência Da Informação 6. Lisboa: Colibri.

Simões, Maria da Graça, and Maria Cristina Vieira de Freitas. 2013. 'A Classificação Em Arquivos e Em Bibliotecas à Luz Da Teoria Da Classificação: Pontos de Convergência e de Divergência'. Ponto de Acesso 7 (1): 81-115. http://hdl.handle.net/10316/36462.

Torres, Sara. 2018. 'Gestão Da Informação Na Câmara Municipal Do Porto'. Páginas A\&b: Arquivos e Bibliotecas, no. Especial: 99-117. https://doi.org/10.21747/21836671/pag2018a8. 